\title{
Effects of pulsatile secretion of growth hormone (GH) on fat deposition in human GH transgenic rats
}

\author{
Yasufumi Furuhata*, Masugi Nishihara and Michio Takahashi*† \\ Department of Veterinary Physiology, Veterinary Medical Science, University of Tokyo, \\ 1-1-1 Yayoi, Bunkyo-ku, Tokyo 113-8657, Japan
}

\begin{abstract}
Growth hormone $(\mathrm{GH})$ is an endocrine regulator of glucose and lipid metabolism as well as body growth. GH levels are decreased and a unique pulsatile secretory pattern becomes obvious after puberty particularly in males. Coincidentally with this, males tend to deposit body fat. Experimental and clinical evidence has accumulated that obesity is associated with a decrease in GH levels. A strain of transgenic rats has been generated with severe obesity but normal nose-to-tail length, which has low circulating GH levels without pulsatility (human growth hormone (hGH) transgenic rats). The present review mainly focuses on recent and current work analysing the relationship between the occurrence of obesity and low GH levels and/or the absence of GH pulsatility in this transgenic animal model. This model has elevated blood glucose, non-esterified fatty acid, insulin and leptin levels associated with hyperphagia, suggesting that these rats also carry insulin- and leptin-resistant characteristics. hGH transgenic rats were subjected to a pair-feeding treatment to normalize food intake and chronic GH replacement to normalize GH levels. While the pair-feeding for 8 weeks successfully suppressed body-weight gain, the fat pad: body weight ratio remained very similar to freely-eating control hGH transgenic rats, which indicates the hyperphagia is not the sole contributor to the excess fat accumulation in this model. However, continuous elevation of peripheral hGH levels (approximately 2 -fold) for 8 weeks by means of a slow-release vehicle resulted in a significant decrease in the fat mass : body weight ratios by $30 \%$. This GH treatment altered neither food intake nor body-weight gain. Thus, two characteristic phenotypes observed in the hGH transgenic rats, hyperphagia and obesity, seem to be closely related to GH levels and GH secretory pattern. This relationship might be working in the regulation of changes in seasonal body composition in wild animals.
\end{abstract}

\section{Growth hormone: Transgenic rats: Obesity: Body composition}

\footnotetext{
Abbreviations: GH, growth hormone; GHD, growth hormone-deficient; hGH, human growth hormone; IRS, insulin receptor substrate; NEFA, non-esterified fatty acid; NIDDM, non-insulin-dependent diabetes mellitus.

*Present address: Research Institute for Health Fundamentals, Ajinomoto Co., Inc., 1-1 Suzuki-cho, Kawasaki-ku, Kawasaki-shi, 210-0801, Japan.

$\dagger$ Corresponding author: Dr M. Takahashi, fax +81 44244 9617, email amtaka@tg7.so-net.ne.jp
} 


\section{Introduction}

Growth hormone $(\mathrm{GH})$ is a prerequisite for enhancing body growth until puberty in man and animals. After puberty, however, GH effects on phenotypic expressions become more ambiguous and the physiological significance of GH secretion seems to be underestimated. Various animal models for analysing physiological activities of GH have been developed. Several lines of transgenic animals carrying a GH transgene have been reported (Kopchick et al. 1999). Due to the over-expression of the transgene, most of these transgenic animals exhibited the gigantic phenotype with an elongated body length. On the other hand, model animals retaining deficiencies either in GH secretion or expression of GH function show the dwarfish phenotype. These GH-excess and -deficient phenotypes in model animals agree with symptoms in acromegalic or GH-deficient (GHD) human subjects.

In GHD human adults, frequent occurrence of fat accumulation was reported, which suggests that GH regulates not only body length but also body composition (Davidson, 1987). Compared with human studies in this context, animal studies have not been sufficiently well developed largely due to difficulty in obtaining good animal models. The animal models for GH deficiency have not been used for the obesity research effectively, because their obesity, if any, is usually compensated by a decrease in body growth and they usually do not exhibit an increase in body weight. However, some recent animal models have been characterized by simultaneous low GH levels and obesity. Transgenic mice carrying a chimeric gene of a metallothionein 1a promoter sequence and ovine $\mathrm{GH}$ gene have been reported whose ovine $\mathrm{GH}$ secretion could be induced by supplementation with $\mathrm{Zn}$ but discontinued by the cessation of the supplementation (Eisen et al. 1998). Congenital GHD dwarf rats fed on a high-fat diet are another animal model (Clark et al. 1996).

Because these animal models express both GH deficiency and obesity symptoms simultaneously, a relationship between GH and obesity was clear. Unfortunately, however, these models have not been utilized effectively to expand the understanding of that relationship until now. The present review highlights some of the authors' recent works towards this goal, by development of a new line of GH transgenic rats expressing both $\mathrm{GH}$ deficiency and obesity.

\section{Characterization of transgenic rats with low circulating growth hormone levels}

Recently, we generated two lines of transgenic rats expressing the human $\mathrm{GH}(\mathrm{hGH})$ gene (Ikeda et al. 1994). As shown in Fig. 1(A), the transgene used consists of mouse whey acidic protein promoter and hGH genome gene. One line had excess circulating hGH and exhibited gigantic phenotypes as expected. The other line, however, had exactly similar body lengths as their non-transgenic littermates and they grew massively fat, contrary to expectations (Ikeda $e t$ al. 1994, 1998; Fig. 1(B)). We used the heterozygotes in all our experiments.

Circulating hGH levels in these obese transgenic rats were continuously low and endogenous GH secretion from the pituitary was severely suppressed. Thus, pulsatile peaks of peripheral GH levels once in 3-4 h, such as those observed in normal male animals, were completely absent (Fig. 1(C)). Both human and rat GH levels in the peripheral circulation of these transgenic rats coincide with the basal levels of intact animals, though there is no definite information about hGH potency in the rat. The reason for the severe inhibition of endogenous $\mathrm{GH}$ secretion could be attributable to the whey acidic protein promoter, which enhances the transcription of the following structure gene in the brain tissue as well as in the mammary glands (Günzburg et al. 1991; Tojo et al. 1993). Thus, the hGH gene might be expressed in the brain of the transgenic rats and inhibit endogenous GH secretion via a short feedback mechanism. 
(A)
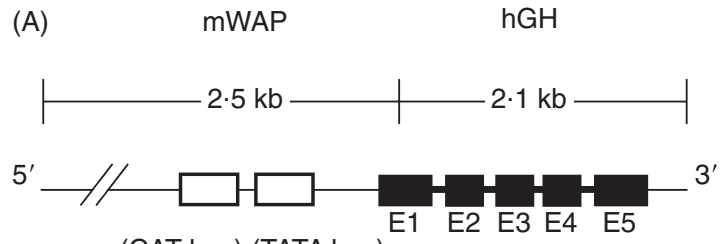

(CAT box) (TATA box)
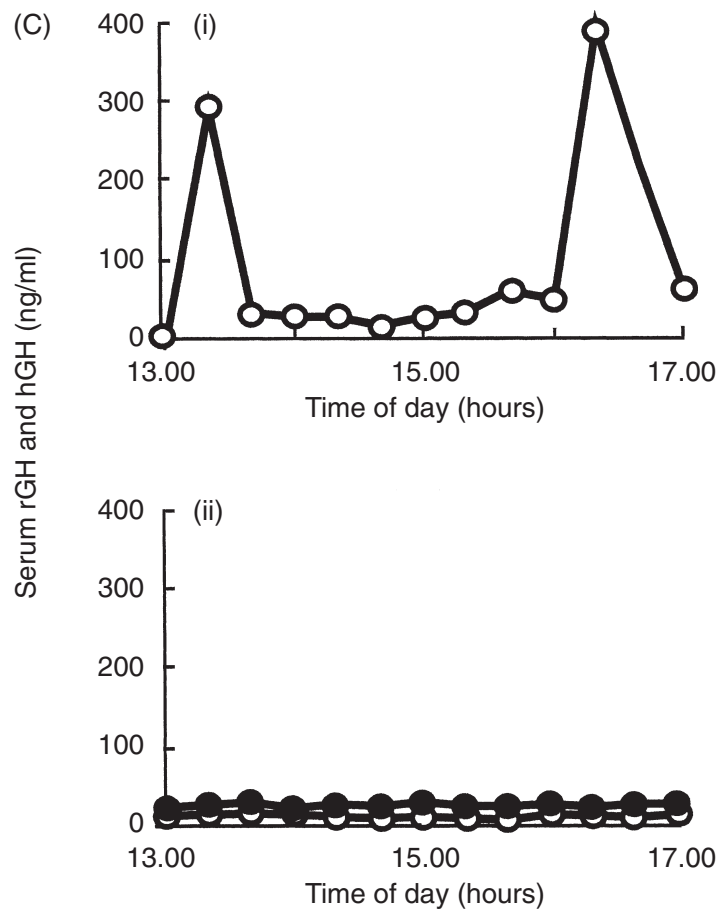

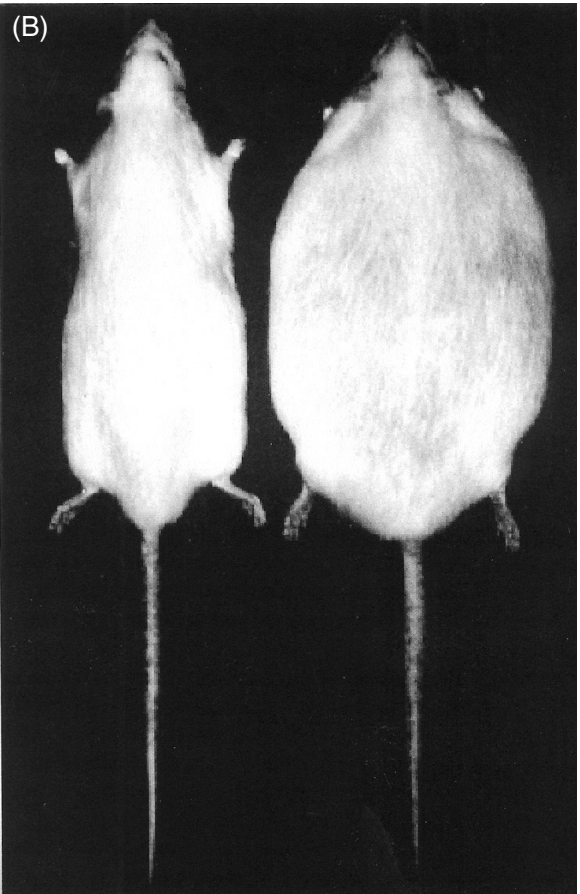

Fig. 1 (A), Construct of the mouse whey acidic protein-human growth hormone (mWAP-hGH) transgene introduced into rats. (B), Representative features of a transgenic rat (right) and its littermate (left) at 23 weeks of age. Body weights of the transgenic rat and its littermate were $1.2 \mathrm{~kg}$ and $560 \mathrm{~g}$, respectively. (C), Representative individual profiles of serum rat growth hormone ( $\left.\mathrm{rGH} ;-\mathrm{O}_{-}\right)$and hGH (-0-) changes over $4 \mathrm{~h}$ in control male (i) and transgenic rat (ii). (From Ikeda et al. 1994, 1998.)

Therefore, the pulsatile pattern of GH secretion was completely abolished in these transgenic animals.

It is known that a gender-dependent GH secretory pattern affects the expression of various types of hepatic steroid metabolic enzymes (Kato \& Yamazoe, 1993). Relative abundance of liver microsomal cytochrome P450 isozymes were analysed in our male transgenic rats and were found to be functionally feminized due to absence of male specific GH pulsatility (Takahashi et al. 1999). This result also confirms that loss of pulsatile secretory pattern of GH occurs in these transgenic rats.

It should be emphasized again that these transgenic animals do not cease GH secretion completely, and that the low levels of GH secreted are enough to maintain normal body growth. The characteristics of GH in these transgenic rats led us to hypothesize that the cause of the severely fat phenotypes might originate from the loss of GH pulses. In this context, we have analysed the relationship between GH function and obesity. 


\section{Causes of obesity in the human growth hormone transgenic rats}

It is widely accepted that GH is an endocrine regulator of protein synthesis and lipolysis as well as of skeletal bone growth (Davidson 1987; de Boer et al. 1995). Moreover, there are reports that obesity is associated with a decrease in GH levels. GH-deficient human subjects have an increased body-fat mass, which can be reduced by GH therapy (Davidson, 1987; Salomon et al. 1989; Bengtsson et al. 1993; de Boer et al. 1995). Beneficial effects of GH on obese (Richelsen et al. 1994) and obese and diet-restricted subjects have been reported (Snyder et al. 1988). In addition, GHD rats and transgenic mice expressing mutant GH exhibit not only dwarfism but also fat accumulation (Turner et al. 1998). Obesity develops ultimately under conditions in which energy intake and expenditure are imbalanced. Increased food intake has been demonstrated in several obese animal models including $o b / o b$ and $d b / d b$ mice (Levin et al. 1996). Interestingly, the circulating GH levels of these animals are depressed (Renier et al. 1990; Veldhuis et al. 1991; Rasmussen et al. 1995), which may also account for their fat accumulation.

As shown in Table 1, the hGH transgenic rats have an increased food intake; in addition, decreased locomotor activity was also observed (Furuhata et al. 2000). A significant increase in body weight in hGH transgenic rats compared with control rats $(P<0.05)$ was first discernible at 13 weeks of age and thereafter they developed severe obesity. However, food intake was already augmented at 4 weeks of age and locomotor activity started to decline from 7 weeks of age, indicating that behavioural changes start much earlier than apparent metabolic abnormalities or abnormal body-weight gain. In addition, we observed that significant fat deposition in the epididymal fat pad of the transgenic rats was already evident at 4 weeks of age $(P<0.05)$ (Ikeda et al. 1998). Taken together, the transgenic rats consume more food and accumulate excess energy in the fat tissue as early as 4 weeks of age due to the impaired GH secretory pattern caused by the transgene product and a decreased locomotor activity.

In order to elucidate how energy imbalance and impaired GH secretion are involved in fat accumulation and metabolic abnormalities in transgenic rats, we utilized a pair-feeding paradigm and chronic GH replacement (Furuhata et al. 2002a). Pair-feeding of the transgenic animals for 8 weeks successfully suppressed body-weight gain and the final body weight was nearly normal (Table 1), indicating that an increase in body weight in the hGH transgenic rats was dependent on an increased energy intake. Although the fat mass in the pair-fed transgenic

Table 1. Effects of pair-feeding and human growth hormone (hGH) treatment in transgenic rats (TG) (From Furuhata et al. 2002a)

\begin{tabular}{|c|c|c|c|c|}
\hline & \multirow[b]{2}{*}{ Control rats } & \multirow[b]{2}{*}{$\mathrm{TG}$} & \multicolumn{2}{|c|}{ Treatment } \\
\hline & & & Pair-feeding & $\mathrm{TG}+\mathrm{hGH}$ \\
\hline Food intake & - & $\Delta$ & $\nabla$ & $\rightarrow$ \\
\hline Growth hormone level & - & $\nabla$ & $\rightarrow$ & $\triangle$ \\
\hline WAT:BW & - & $\boldsymbol{\Delta}$ & $\rightarrow$ & $\nabla$ \\
\hline Triacylglycerol & - & $\Delta$ & $\nabla$ & $\rightarrow$ \\
\hline NEFA & - & 4 & $\rightarrow$ & $\rightarrow$ \\
\hline Insulin & - & $\Delta$ & $\nabla$ & $\rightarrow$ \\
\hline Leptin & - & $\boldsymbol{4}$ & $\nabla$ & $\nabla$ \\
\hline
\end{tabular}

WAT, white adipose tissue mass; BW, body weight; NEFA, non-esterified fatty acid;

$\rightarrow$, change compared with Control; $\rightarrow$, change compared with TG without treatment. 
animals became significantly smaller than that in the transgenic rats fed ad libitum $(P<0 \cdot 05)$, it still was two times heavier than those in the non-transgenic littermates. In addition, the fat pad : body weight ratios were not significantly different between the pair-fed and freely-eating transgenic animals (Table 1). Thus, the fat accumulation observed in the hGH transgenic rats is not solely attributable to an increase in food intake.

Continuous elevation of peripheral hGH levels (approximately 2 -fold) for 8 weeks by means of a slowly releasing vehicle resulted in a decrease in the fat mass : body weight ratios by $30 \%$ in the transgenic rats, though it did not affect food intake or body weight (Table 1). In our previous report, intermittent hGH treatment during daytime at $3 \mathrm{~h}$ intervals for 1 week was found to normalize completely the body-weight gain during the treatment period (Ikeda et al. 1998). Taken together, these results suggest that the severe fat accumulation observed in the hGH transgenic rats can be attributed to a decrease in lipolytic action of GH rather than an enhanced food intake.

Lipolytic action of GH is well documented both in vivo (Beauville et al. 1992; Kamel et al. 2000) and in vitro (Goodman \& Grichting, 1983; Fielder \& Talamantes, 1987), but the signalling mechanism by which $\mathrm{GH}$ regulates that process is yet to be fully explored. In adipocytes isolated from obese children after chronic GH treatment, catecholamine-induced lipolysis is increased maximally (Kamel et al. 2000). This increased sensitivity of adipocytes to lipolysis is reproduced by terbutaline but not by isoprenalin, indicating that the lipolytic effect of $\mathrm{GH}$ is related to the enhancement of the $\beta 2$-adrenoreceptor itself and/or its signalling pathway in adipocytes (Kamel et al.2000). GH stimulates lipolysis through an inhibitory action on the $\mathrm{G}$ protein $\mathrm{Gi}$, thereby increasing cAMP accumulation that results in lypolysis (Yip \& Goodman, 1999). An involvement of STAT5 proteins in this lypolytic action has also been reported (Fain et al. 1999). On the other hand, GH appears to inhibit adipocyte differentiation at a step before the induction of genes required for terminal differentiation, such as peroxisome proliferator activated receptor $\gamma$ (Hansen et al. 1998). Fat accumulation observed in the transgenic rats may not be related to the stimulation of adipocyte differentiation because we could not find an increase in the number of adipocytes in the transgenic rats (Ikeda et al. 1998).

\section{Metabolic abnormalities in transgenic rats}

Obesity is frequently associated with metabolic abnormalities and hyperinsulinaemia and hyperlipidaemia were observed in the transgenic rats (Table 1). Pair-feeding of the hGH transgenic rats with control littermates almost completely ameliorated hyperinsulinaemia (Furuhata et al. 2002a). By pair-feeding, the weight of the fat pad decreased but still remained significantly heavier than controls $(P<0 \cdot 05)$. Therefore, hyperinsulinaemia in the transgenic rats was not attributable to excess fat accumulation. Moreover, continuous elevation of peripheral hGH levels (approximately 2-fold) for 8 weeks did not affect serum insulin levels, though this treatment reduced fat pad mass. Therefore, the hyperphagia was likely to have been one of the major reasons for hyperinsulinaemia in the $\mathrm{hGH}$ transgenic rats, but excess fat accumulation did not play a major role for the development of hyperinsulinaemia.

Since elevated circulating triacylglycerol levels were normalized by pair-feeding, hypertriacylglycerolaemia in these rats could also be explained by excessive energy intake (Table 1). However, pair-feeding did not affect serum non-esterified fatty acid (NEFA) levels in the transgenic rats. One possible explanation for this result could be the fact that fat mass was still 2fold heavier in pair-fed transgenic rats, because it has been shown that circulating NEFA concentration is well correlated with the adipose tissue mass (Bjorntorp et al. 1969). hGH treatment, on the other hand, did not significantly affect serum NEFA levels, though the treatment 
significantly reduced fat accumulation in the transgenic animals $(P<0.05)$. Presence of high NEFA levels in the hGH-treated rats may be a consequence of lipolysis by hGH, because it is reported that GH treatment of obese human subjects reduces fat accumulation and elevates circulating NEFA levels (Richelsen et al. 1994).

Pair-feeding of the hGH transgenic rats almost completely normalized serum leptin levels and it has been reported that adipocytes pretreated with insulin secrete larger amounts of leptin (Cusin et al. 1995; Saladin et al. 1995). Fasting reduces leptin levels coincidentally with lowering of insulin levels (Trayhurn et al. 1999), which suggests that the decrease in serum leptin levels in the pair-fed hGH transgenic rats was attributable to the lowered serum insulin levels. On the other hand, hGH treatment partially corrected serum leptin levels without affecting serum insulin. In GHD adults, increased circulating leptin levels were observed (Bjarnason et al. 1997; Fisker et al. 1997) and this hyperleptinaemia could be normalized by GH therapy. Under in vitro conditions, GH does not affect adipocyte leptin expression or secretion (Hardie et al. 1996) and therefore it is likely that leptin levels in GHD adults would reflect body composition rather than GH status. The primary cause for a decrease in serum leptin levels in the hGH-treated transgenic rats would be a lipolytic action of GH that decreases the fat pad mass.

\section{Insulin resistance}

GH is known to modulate insulin actions (Davidson, 1987) and GHD subjects have long been recognized as exhibiting increased insulin sensitivity. In fact, the occurrence of fasting hypoglycaemia has been demonstrated in GHD children (Wolfsdorf et al. 1983) and adults (Merimee et al. 1971). Studies using animal models such as dwarf rats (Daugaard et al. 1999) and GH receptor-knockout mice (Dominici et al. 2000) support this notion. In contrast, several researchers have recently reported observing insulin resistance in GHD subjects. Cuneo et al. (1992) reported increased fasting insulin levels in GHD adults. Decreased insulin sensitivity was also shown in GHD adults by the euglycaemic-hyperinsulinaemic clamp method (Johansson et al. 1995; Hew et al. 1996). In addition, the studies of GHD subjects have shown increased fat accumulation, which is one of the major risk factors for developing non-insulindependent diabetes mellitus (NIDDM) with insulin resistance (Kopelman, 2000); insulin resistance can occur in the state of GH deficiency. In contrast with clinical studies, there have been few reports of studies to investigate the relationship between insulin resistance and GH deficiency in animal models. One reason may be that until recently, no good animal models that exhibit both insulin resistance and GH deficiency were available.

The hGH transgenic rats with low circulating levels of GH develop insulin resistance as well as severe obesity. As described earlier, insulin, triacylglycerol and NEFA levels, which are known to be indicators of early diabetes, are all elevated. In addition, an elevation of blood glucose level and glucose intolerance after a bolus injection of glucose are observed in these transgenic rats (Ikeda et al. 1998; Furuhata et al. 2002b). Thus, we believe our transgenic rats are useful model animals for investigating the relationship between insulin resistance and impaired GH status.

We have analysed insulin signalling in the liver of the hGH transgenic rats to explore whether insulin resistance could actually be detected and the targets for this purpose are shown in Fig. 2. Insulin signalling is initiated by the activation of insulin receptor tyrosine kinase, leading to the phosphorylation of intracellular receptor substrates, including insulin receptor substrates (IRS)-1 and -2, which contain over twenty potential tyrosine phosphorylation sites (Sun et al. 1993, 1995). The possible tyrosine phosphorylation sites are highly conserved 


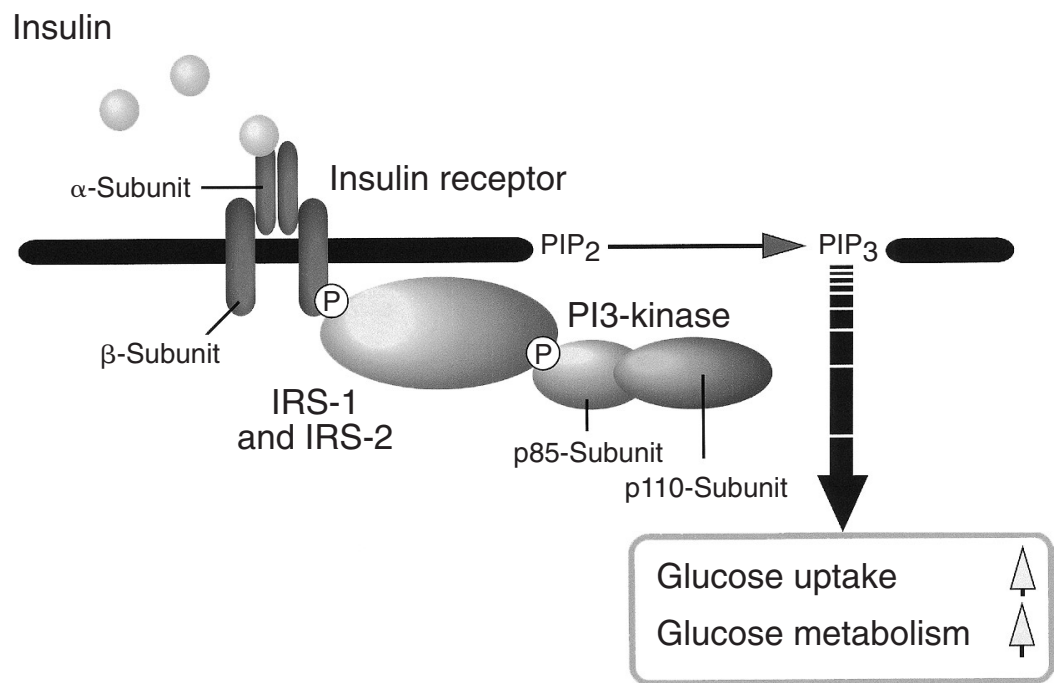

Fig. 2. Insulin receptor signalling pathway. Insulin signalling is initiated by the activation of insulin receptor tyrosine kinase, leading to the phosphorylation of intracellular receptor substrates, including insulin receptor substrates (IRS) -1 and -2 . The motifs containing phosphorylated tyrosine residues in IRS-1 and IRS-2 could bind to the p85 subunit of phosphatidylinositol 3-kinase (PI3-kinase) and then the p110 subunit of PI3-kinase is activated. PIP, phosphatidylinositol. (From Kanai et al. 1993; Cheatham et al. 1994; Okada et al. 1994.)

between IRS-1 and IRS-2 (Sun et al. 1995). The motifs containing phosphorylated tyrosine residues in IRS-1 and IRS-2 serve as docking sites for binding to various proteins having the Src homology-2 domain. Among these Src homology-2 proteins, phosphatidylinositol 3-kinase is considered to be particularly important for the insulin-induced glucose uptake that is observed in muscle and adipose tissue via the translocation of a glucose transporter to the plasma membrane (Kanai et al. 1993; Cheatham et al. 1994; Okada et al. 1994). Furthermore, the activation of phosphatidylinositol 3-kinase was reported to play an important role in insulin-induced glycogen synthesis and suppression of phosphoenolpyruvate carboxykinase gene expression in hepatocytes (Sakaue et al. 1995; Shepherd et al. 1995; Sutherland et al. 1995; Gabbay et al. 1996).

We first measured the amount of insulin receptor in the liver of transgenic rats by Western blotting and found that insulin receptor levels were lowered (Furuhata et al. 2002b). Insulinstimulated phosphorylation of insulin receptor was also proportionally suppressed in the transgenic rats, indicating that insulin resistance in the liver is initiated at the receptor level. The amounts of both IRS- 1 and -2 proteins in the liver of the transgenic rats were reduced compared with that of controls. Moreover, phosphorylated tyrosine of IRS-1 and -2 and phosphatidylinositol 3-kinase activity associated with these proteins were also decreased. These results suggest that the liver of the hGH transgenic rats is somehow insulin resistant.

One of the candidates that suppresses insulin sensitivity in the transgenic rats is hyperinsulinaemia. There are reports of down regulation of insulin receptors under high circulating insulin levels (Gavin et al. 1974; Kahn et al. 1978; Vigneri et al. 1978; Almira \& Reddy, 1979). However, it has also been reported that GH does not directly affect insulin receptor levels either in vivo (Dominici et al. 1998) or in vitro (Lesniak \& Roth, 1976; Maloff et al. 1980). In the hGH transgenic rats, elevated circulating insulin levels are observed after 12 weeks of age (Ikeda et al. 1998) and therefore the decreased insulin receptor levels described earlier could be the result of hyperinsulinaemia rather than from low GH levels. 
It has been reported that IRS-1 protein was moderately increased in the liver of streptozotocin-treated rats, in which insulin was virtually absent (Saad et al. 1992). Conversely, hyperinsulinaemic ob/ob mice and Zucker rats showed reduced IRS-1 (Saad et al. 1992) and both IRS-1 and -2 (Anai et al. 1998) proteins in the liver, respectively. These findings suggest that IRS-1 and -2 levels are inversely related to circulating insulin levels so that decreased IRS-1 and -2 in the liver of the hGH transgenic rats may be related to hyperinsulinaemia. Because transgenic mice over-expressing GH display normal concentrations of IRS-1 in the liver despite hyperinsulinaemia (Dominici et al. 1999), a possibility that other factors, such as changes in the concentrations of glucose or counter-regulatory hormones (including $\mathrm{GH}$ ), are involved in the regulation of IRS levels cannot be ruled out. We discussed earlier that increased hyperinsulinaemia in the hGH transgenic rats results from an excess energy intake, but it remains to be elucidated whether or not restriction of energy intake restores insulin resistance in the transgenic rats.

Basal levels of tyrosine phosphorylation of IRS-1 in the hGH transgenic rats were significantly lowered. This may be secondary to the decreased IRS-1 protein level. The amount of IRS-2 was also decreased, but no significant difference in basal tyrosine phosphorylation levels of IRS-2 was observed between the transgenic and control rats, suggesting a different regulatory mechanism for the basal tyrosine phosphorylation level of IRS-1 and -2 in the liver. GH has been shown to stimulate tyrosine phosphorylation of IRS-1 in vivo (Yamauchi et al. 1998; Thirone et al. 1999). Further, Dominici et al. (1999) reported that GH transgenic mice showed an increased basal tyrosine phosphorylation of IRS-1, which, they suggested, may be one of the causes of insulin resistance in those mice. Thus, altered GH levels, either higher or lower than normal, may affect basal tyrosine phosphorylation of IRS-1 in the liver. These findings suggest that GH has an important role for maintaining insulin sensitivity in the liver. In this context, a cross-talk mechanism between $\mathrm{GH}$ and insulin signal transduction can be hypothesized for the development of insulin resistance in the liver.

Serine and threonine phosphorylations in IRS proteins may be also involved in impaired insulin signalling in transgenic rats. It has been demonstrated that serine and threonine phosphorylation of IRS-1 impairs the ability of IRS-1 to associate with the insulin receptor, which inhibits subsequent insulin-stimulated tyrosine phosphorylation (Paz et al. 1997). In addition, it has also been reported that serine and threonine phosphorylation in IRS-1 is increased in subjects with insulin resistance and NIDDM (Virkamaki et al. 1999) and that cytokines, which induce insulin resistance, promote serine phosphorylation of IRS-1 (Kanety et al. 1995; Hotamisligil et al. 1996; Peraldi et al. 1996). Taken together, serine and threonine phosphorylation in IRS proteins seems to play an important role in the development of insulin resistance.

\section{Leptin resistance}

As described earlier, failure of energy balance causes obesity and metabolic abnormalities. Why does hyperphagia occur in the hGH transgenic rats? Leptin, a $16 \mathrm{kDa}$ peptide hormone, for which the gene was positionally cloned in 1994 (Zhang et al. 1994), is an adipocyte-derived hormone that decreases food intake and increases energy expenditure, thereby leading to a marked reduction in body weight (Pelleymounter et al. 1995, Levin et al. 1996). It has been reported that the absence of leptin or functional leptin receptor causes massive obesity and NIDDM, similar to previously known animal models, i.e. ob/ob mice or Zucker fatty rats (Zhang et al. 1994; Ghilardi et al. 1996; Lee et al. 1996). Leptin levels correlate with specific estimates of body fat (Hickey et al. 1996; Rosenbaum et al. 1996) and reducing the obesity 
decreases the high leptin concentrations in obese human subjects. In obese individuals, however, high plasma leptin levels do not induce anorexic responses theoretically expected and this inconsistency has led to the concept of leptin resistance (Caro et al. 1996; Bjarnason et al. 1997). In obese GHD human adults, an increased circulating leptin is observed (Bjarnason et al. 1997; Fisker et al. 1997; Janssen et al. 1997), therefore we analysed our obese and GH-deficient hGH transgenic animals to determine whether or not they were leptin-resistant.

As mentioned already, the transgenic rats have much increased leptin levels, despite which, food intake is enhanced and locomotor activity suppressed. Thus, the hGH transgenic rats are leptin-resistant phenotypically. This conclusion was further supported by the observation that systemic administration of leptin, which decreased food intake and increased locomotor activity in the control rats, did not affect these parameters in the transgenic rats (Furuhata et al. 2000). Interestingly, however, direct administration of leptin into the brain was effective to a similar extent in both the transgenic and control rats, suggesting a dysfunction of transmission of peripheral leptin signals to the central nervous system in the transgenic rats.

The biological actions of leptin are thought to be mediated largely through interactions with its receptors that are expressed in the hypothalamus (Tartaglia et al. 1995). Because the leptin molecule seems too large to cross the blood-brain barrier, it appears to be transported into the brain by a saturable system (Banks et al. 1996; McKinley \& Oldheld, 1998). Thus, while there is a correlation between plasma and cerebrospinal fluid levels of leptin, the relationship is logarithmic rather than linear and recently, this relationship has been postulated as one of the causes of leptin resistance in man (Caro et al. 1996; Schwartz et al. 1996). In the present study (Furuhata et al. 2000), we found that even though circulating leptin levels were much higher in the transgenic than in the control rats, cerebrospinal fluid leptin levels were not different. This observation provides experimental evidence that leptin resistance occurs at least partially at the level of transportation of leptin into the brain (Fig. 3).

The leptin receptor is a single transmembrane-spanning protein that resembles gp130, a member of the class I cytokine receptor superfamily (Banks et al. 1996). The leptin receptor

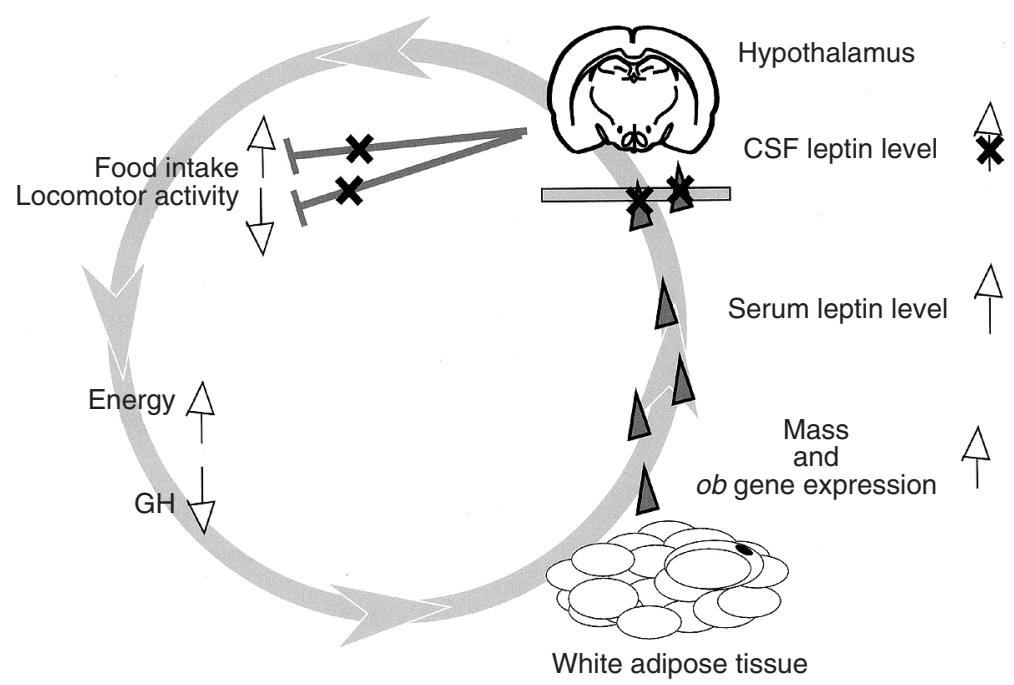

Fig. 3. Leptin resistance may contribute to the development of obesity in the transgenic rats. Low circulating growth hormone $(\mathrm{GH})$ levels and energy imbalance induce fat accumulation and hyperleptinaemia. However, although circulating leptin level is increased, it could not be transported into the brain efficiently, resulting in excessive energy balance. CSF, cerebrospinal fluid. (From Caro et al. 1996; Schwartz et al. 1996; Furuhata et al. 2000.) 
has five or more splice variants expressed in a tissue-specific fashion (Chen et al. 1996; Chua et al. 1996). Wu-Peng et al. (1997) have reported that the leptin receptor itself is one of the candidates for a leptin transporter. It is especially likely that OB-Ra, a short form of leptin receptor, is the transporter molecule accounting for uptake into the brain, since it is expressed in the choroid plexus. Recently, Burguera et al. (2000) have reported that the leptin transport system is saturated near physiological concentrations in lean individuals, which implies that the elevated leptin levels observed in obesity can produce no biological effects because the system is already saturated. In this regard, the leptin transport system in the transgenic rats could be already saturated, so that they have no response in appetite to peripheral administration of leptin. The early onset of behavioural changes suggests the early onset of leptin resistance, which is presumably one of the primary causes of obesity in the transgenic rat with low circulating levels of $\mathrm{GH}$.

In our experimental paradigm, where continuous elevation of peripheral hGH levels (approximately 2-fold higher than those in the non-treated transgenic rats) was maintained for 8 weeks, serum leptin levels in the treated transgenic rats were lowered partially but not completely. The possibility cannot be excluded that an alternate method of treatment, such as one simulating pulsatile GH secretion, could have restored leptin resistance more efficiently.

\section{General considerations}

GH is not an essential hormone for survival, since GHD models are not lethal. Moreover, although they are dwarves, it has been reported that they have a longer life span compared with GH normal individuals (Brown-Borg et al. 1996). GH, however, induces the growth of bone and muscle directly or indirectly. This effect must have evolutionary advantages particularly for competition for survival among individuals of the same species. In addition, GH must have a function of changing body composition in order to adapt individuals to various natural environments. Wild animals, such as birds before migration, hibernants before hibernation or male fur seals before making a harem, store large amounts of fat in preparation for the future deficiency in food intake. Hibernation is a strategy employed by particular mammals during periods of climatic challenge associated with reduced food availability. During hibernation, metabolism, body temperature and basic behaviours such as eating are greatly reduced and energy must be stored as fat during the pre-hibernatory period, often leading to a doubling of body mass (Mrosovsky, 1976; Young, 1976; Boyer et al. 1997; Kunz et al. 1998). Because GH pulses are instituted by neural mechanisms including GH releasing hormone and somatostatin neuronal systems, GH pulsatility, at least theoretically, can be stopped by those same neuronal mechanisms, which in turn promotes efficient fat deposition. Based on our observations on hGH transgenic rats, the prevalence of obesity in aged men and women could be attributed to the attenuation of GH pulsatility with age that epidemiological study confirms.

\section{References}

Almira EC \& Reddy WJ (1979) Effect of fasting on insulin binding to hepatocytes and liver plasma membranes from rats. Endocrinology 104, 205-211.

Anai M, Funaki M, Ogihara T, Terasaki J, Inukai K, Katagiri H, Fukushima Y, Yazaki Y, Kikuchi M, Oka Y \& Asano T (1998) Altered expression levels and impaired steps in the pathway to phosphatidylinositol 3-kinase activation via insulin receptor substrates 1 and 2 in Zucker fatty rats. Diabetes 47, 13-23.

Banks WA, Huang AJ, Jaspan JB \& Maness LM (1996) Leptin enters the brain by a saturable system independent of insulin. Peptides 17, 305-311. 
Beauville M, Harant I, Crampes F, Riviere D, Tauber MT, Tauber JP \& Garrigues M (1992) Effect of long-term rhGH administration in GH-deficient adults on fat cell epinephrine response. American Journal of Physiology 263, E467-E472.

Bengtsson BA, Eden S, Lonn L, Kvist H, Stokland A, Lindstedt G, Bosaeus I, Tolli J, Sjostrom L \& Isaksson OG (1993) Treatment of adults with growth hormone (GH) deficiency with recombinant human GH. Journal of Clinical Endocrinology and Metabolism 76, 309-317.

Bjarnason R, Boguszewski M, Dahlgren J, Gelander L, Kristrom B, Rosberg S, Carlsson B, Albertsson-Wikland K \& Carlsson LM (1997) Leptin levels are strongly correlated with those of GH-binding protein in prepubertal children. European Journal of Endocrinology 137, 68-73.

Bjorntorp P, Bergman H, Varnauskas E \& Lindholm B (1969) Lipid mobilization in relation to body composition in man. Metabolism: Clinical and Experimental 18, 840-851.

Boyer BB, Ormseth OA, Buck L, Nicolson M, Pelleymounter MA \& Barnes BM (1997) Leptin prevents posthibernation weight gain but does not reduce energy expediture in arctic ground squirrels. Comparative Biochemistry and Physiology 118C, 405-412.

Brown-Borg HM, Borg KE, Meliska CJ \& Bartke A (1996) Dwarf mice and the ageing process. Nature 384, 33.

Burguera B, Couce ME, Curran GL, Jensen MD, Lloyd RV, Cleary MP \& Poduslo JF (2000) Obesity is associated with a decreased leptin transport across the blood-brain barrier in rats. Diabetes 49, 1219-1223.

Caro JF, Kolaczynski JW, Nyce MR, Ohannesian JP, Opentanova I \& Goldman WH (1996) Decreased cerebrospinalfluid serum leptin ratio in obesity: a possible mechanism for leptin resistance. Lancet 348, 159-161.

Cheatham B, Vlahos CJ, Cheatham L, Wang L, Blenis J \& Kahn CR (1994) Phosphatidylinositol 3-kinase activation is required for insulin stimulation of pp70 S6 kinase, DNA synthesis, and glucose transporter translocation. Molecular and Cellular Biology 14, 4902-4911.

Chen H, Charlat O, Tartaglia LA, Woolf EA, Weng X, Ellis SJ, Lakey ND, Culpepper J, Moore KJ, Breitbart RE, Duyk GM, Tepper RI \& Morgenstern JP (1996) Evidence that the diabetes gene encodes the leptin receptor: Identification of a mutation in the leptin receptor gene in $\mathrm{db} / \mathrm{db}$ mice. Cell 84, 491-495.

Chua SC, Chung WK, Wu-peng XS, Zhang Y, Liu SM, Tartaglia L, \& Leibel RL (1996) Phenotypes of mouse diabetes and rat fatty due to mutations in the OB (Leptin) receptor. Science 271, 994-996.

Clark RG, Mortensen DL, Carlsson LM, Carlsson B, Carmignac D \& Robinson IC (1996) The obese growth hormone (GH)-deficient dwarf rat: body fat responses to patterned delivery of $\mathrm{GH}$ and insulin-like growth factor-I. Endocrinology 137, 1904-1912.

Cuneo RC, Salomon F, McGauley GA \& Sonksen PH (1992) The growth hormone deficiency syndrome in adults. Clinical Endocrinology 37, 387-397.

Cusin I, Sainsbury A, Doyle P, Rohner-Jeanrenaud F \& Jeanrenaud B (1995) The ob gene and insulin. A relationship leading to clues to the understanding of obesity. Diabetes 44, 1467-1470.

Daugaard JR, Laustsen JL, Hansen BS \& Richter EA (1999) Insulin action in growth hormone-deficient and agematched control rats: effect of growth hormone treatment. Journal of Endocrinology 160, 127-135.

Davidson MB (1987) Effect of growth hormone on carbohydrate and lipid metabolism. Endocrine Reviews 8, 115-131.

de Boer H, Blok GJ \& Van der Veen EA (1995) Clinical aspects of growth hormone deficiency in adults. Endocrine Reviews 16, 63-86.

Dominici FP, Arostegui Diaz G, Bartke A, Kopchick J \& Turyn D (2000) Compensatory alterations of insulin signal transduction in liver of growth hormone receptor knockout mice. Journal of Endocrinology 166, 579-590.

Dominici FP, Balbis A, Bartke A \& Turyn D (1998) Role of hyperinsulinemia on hepatic insulin receptor concentration and autophosphorylation in the presence of high growth hormone levels in transgenic mice overexpressing growth hormone gene. Journal of Endocrinology 159, 15-25.

Dominici FP, Cifone D, Bartke A \& Turyn D (1999) Loss of sensitivity to insulin at early events of the insulin signaling pathway in the liver of growth hormone-transgenic mice. Journal of Endocrinology 161, 383-392.

Eisen EJ, Peterson CB, Parker IJ \& Murray JD (1998) Effects of zinc ion concentration on growth, fat content and reproduction in oMT1a-oGH transgenic mice. Growth, Development, and Aging 62, 173-186.

Fain JN, Ihle JH \& Bahouth SW (1999) Stimulation of lipolysis but not of leptin release by growth hormone is abolished in adipose tissue from Stat5a and b knockout mice. Biochemical and Biophysical Research Communications 263, 201-205.

Fielder PJ \& Talamantes F (1987) The lipolytic effects of mouse placental lactogen, mouse prolactin, and mouse growth hormone on adipose tissue from virgin and pregnant mice. Endocrinology 121, 493-497.

Fisker S, Vahl N, Hansen TB, Jorgensen JO, Hagen C, Orskov H \& Christiansen JS (1997) Serum leptin is increased in growth hormone-deficient adults: relationship to body composition and effects of placebo-controlled growth hormone therapy for 1 year. Metabolism: Clinical and Experimental 46, 812-817.

Furuhata Y, Hirabayashi K, Yonezawa T, Takahashi M \& Nishihara M (2002a) Effects of pair-feeding and growth hormone treatment on obese transgenic rats. European Journal of Endocrinology 146, 245-249.

Furuhata Y, Kagaya R, Hirabayashi K, Ikeda A, Chang KT, Nishihara M \& Takahashi M (2000) Development of obesity in transgenic rats with low circulating growth hormone levels: involvement of leptin resistance. European Journal of Endocrinology 143, 535-541.

Furuhata Y, Yonezawa T, Takahashi M \& Nishihara M (2002b) Impaired insulin signaling in the liver of transgenic rats with low circulating growth hormone. Journal of Endocrinology 172, 127-136. 
Gabbay RA, Sutherland C, Gnudi L, Kahn BB, O`Brien RM, Granner DK \& Flier JS (1996) Insulin regulation of phosphoenolpyruvate carboxykinase gene expression does not require activation of the Ras/mitogen-activated protein kinase signaling pathway. Journal of Biological Chemistry 271, 1890-1897.

Gavin JR III, Roth J, Neville DM Jr, Meyts PD \& Buell DN (1974) Insulin-dependent regulation of insulin receptor concentrations: a direct demonstration in cell culture. Proceedings of the National Academy of Sciences USA 71, 84-88.

Ghilardi N, Zingler S, Wiestner A, Soffel R \& Heim MH (1996) Defective STAT signaling by leptin receptor in diabetic mice. Proceedings of the National Academy of Sciences USA 93, 6231-6235.

Goodman HM \& Grichting G (1983) Growth hormone and lipolysis: a reevaluation. Endocrinology 113, $1697-1702$.

Günzburg WH, Salmons B, Zimmermann B, Müller M, Erfle V \& Brem G (1991) A mammary-specific promoter directs expression of growth hormone not only to the mammary gland, but also to bergman glia cells in transgenic mice. Molecular Endocrinology 5, 123-133.

Hansen LH, Madsen B, Teisner B, Nielsen JH \&Billestrup N (1998) Characterization of the inhibitory effect of growth hormone on primary preadipocyte differentiation. Molecular Endocrinology 12, 1140-1149.

Hardie LJ, Guilhot N \& Trayhurn P (1996) Regulation of leptin production in cultured mature white adipocytes. Hormone and Metabolic Research 28, 685-689.

Hew FL, Koschmann M, Christopher M, Rantzau C, Vaag A, Ward G, Beck-Nielsen H \& Alford F (1996) Insulin resistance in growth hormone-deficient adults: defects in glucose utilization and glycogen synthase activity. Journal of Clinical Endocrinology and Metabolism 81, 555-564.

Hickey MS, Israel RG, Gardiner SN, Considine RV, McCammon MR, Tyndall GL, Houmard JA, Marks RH \& Caro JF (1996) Gender differences in serum leptin levels in humans. Biochemical Molecular Medicine 59, 591-616.

Hotamisligil GS, Peraldi P, Budavari A, Ellis R, White MF \& Spiegelman BM (1996) IRS-1-mediated inhibition of insulin receptor tyrosine kinase activity in TNF-alpha- and obesity-induced insulin resistance. Science 271, 665-668.

Ikeda A, Chang KT, Matsumoto Y, Furuhata Y, Nishihara M, Sasaki F \& Takahashi M (1998) Obesity and insulin resistance in human growth hormone transgenic rats. Endocrinology 139, 3057-3063.

Ikeda A, Matsuyama S, Nishihara M, Tojo H \& Takahashi M (1994) Changes in endogenous growth hormone secretion and onset of puberty in transgenic rats expressing human growth hormone gene. Endocrine Journal 41, 523-529.

Janssen YJH, Frolich M, Deurenberg P \& Roelfsema F (1997) Serum leptin levels during recombinant human GH therapy in adults with GH deficiency. European Journal of Endocrinology 137, 650-654.

Johansson JO, Fowelin J, Landin K, Lager I \& Bengtsson BA (1995) Growth hormone-deficient adults are insulinresistant. Metabolism: Clinical and Experimental 44, 1126-1129.

Kahn CR, Goldfine ID, Neville DM Jr \& De Meyts P (1978) Alterations in insulin binding induced by changes in vivo in the levels of glucocorticoids and growth hormone. Endocrinology 103, 1054-1066.

Kamel A, Norgren S, Elimam A, Danielsson P \& Marcus C (2000) Effects of growth hormone treatment in obese prepubertal boys. Journal of Clinical Endocrinology \& Metabolism 85, 1412-1419.

Kanai F, Ito K, Todaka M, Hayashi H, Kamohara S, Ishii K, Okada T, Hazeki O, Ui M \& Ebina Y (1993) Insulin-stimulated GLUT4 translocation is relevant to the phosphorylation of IRS-1 and the activity of PI3-kinase. Biochemical anad Biophysical Research Communications 195, 762-768.

Kanety H, Feinstein R, Papa MZ, Hemi R \& Karasik A (1995) Tumor necrosis factor $\alpha$-induced phosphorylation of insulin receptor substrate-1 (IRS-1). Possible mechanism for suppression of insulin-stimulated tyrosine phosphorylation of IRS-1. Journal of Biological Chemistry 270, 23780-23784.

Kato R \& Yamazoe Y (1993) Hormonal regulation of cytochrome P450 in rat liver. In Cytochrome P450: Handbook of Experimental Pharmacology, vol. 105 pp. 447-459 [BS John and G Helmut, editors]. Berlin: Springer.

Kopchick JJ, Bellush LL \& Coschigano KT (1999) Transgenic models of growth hormone action. Annual Review of Nutrition 19, 437-461.

Kopelman PG (2000) Obesity as a medical problem. Nature 404, 635-643.

Kunz TH, Wrazen JA \& Burnett CD (1998) Changes in body mass and body composition in pre-hibernating little brown bats (Myotis lucifugus). Ecoscience 5, 8-17.

Lee GH, Proenca R, Montez JM, Carroll KM, Darvishzadeh JG, Lee JI \& Friedman JM (1996) Abnormal splicing of the leptin receptor in diabetic mice. Nature 379, 632-635.

Lesniak MA \& Roth J (1976) Regulation of receptor concentration by homologous hormone. Effect of human growth hormone on its receptor in IM-9 lymphocytes. Journal of Biological Chemistry 251, 3720-3729.

Levin N, Nelson C, Gurney A, Vandlen R \& de Sauvage F (1996) Decreased food intake does not completely account for adiposity reduction after ob protein infusion. Proceedings of the National Academy of Sciences of the United States of America 93, 1726-1730.

McKinley MJ \& Oldfield BJ (1998) The brain as an endocrine target for peptide hormones. Trends in Endocrinology and Metabolism 9, 349-354.

Maloff BL, Levine JH \& Lockwood DH (1980) Direct effects of growth hormone on insulin action in rat adipose tissue maintained in vitro. Endocrinology 107, 538-544.

Merimee TJ, Felig P, Marliss E, Fineberg SE \& Cahill GG Jr (1971) Glucose and lipid homeostasis in the absence of human growth hormone. Journal of Clinical Investigation 50, 574-582.

Mrosovsky N (1976) Lipid programs and life strategies in hibernators. American Zoologist 16, 685-697.

Okada T, Kawano Y, Sakakibara T, Hazeki O \& Ui M (1994) Essential role of phosphatidylinositol 3-kinase in insulininduced glucose transport and antilipolysis in rat adipocytes. Studies with a selective inhibitor wortmannin. Journal of Biological Chemistry 269, 3568-3573. 
Paz K, Hemi R, LeRoith D, Karasik A, Elhanany E, Kanety H \& Zick Y (1997) A Molecular Basis for Insulin Resistance. Journal of Biological Chemistry 272, 29911-29918.

Pelleymounter MA, Cullen MJ, Baker MB, Hecht R, Winters D, Boone T \& Collins F (1995) Effects of the obese gene product on body weight regulation in $o b / o b$ mice. Science $\mathbf{2 6 9}, 540-543$.

Peraldi P, Hotamisligil GS, Buurman WA, White MF \& Spiegelman BM (1996) Tumor necrosis factor (TNF)-alpha inhibits insulin signaling through stimulation of the p55 TNF receptor and activation of sphingomyelinase. Journal of Biological Chemistry 271, 13018-13022.

Rasmussen MH, Hvidberg A, Juul A, Main KM, Gotfredsen A, Skakkebaek NE, Hilsted J \& Skakkebaek NE (1995) Massive weight loss restores 24-hour growth hormone release profiles and serum insulin-like growth factor-I levels in obese subjects. Journal of Clinical Endocrinology and Metabolism 80, 1407-1415.

Renier G, Gaudreau P, Hajjad H, Deslauriers N, Houde-Nadeau M \& Brazeau P (1990) Decreased pituitary growth hormone response to growth hormone-releasing factor in cafeteria-fed rats: dietary and obesity effects. Neuroendocrinology 52, 284-290.

Richelsen B, Pedersen SB, Borglum JD, Moller-Pedersen T, Jorgensen J \& Jorgensen JO (1994) Growth hormone treatment of obese women for 5 wk: effect on body composition and adipose tissue LPL activity. American Journal of Physiology 266, E211-E216.

Rosenbaum M, Nicolson M, Hirsch J, Murphy E, Chu F \& Leibel RL (1996) Effects of gender, body composition, and menopause on plasma concentrations of leptin. Journal of Clinical Endocrinology and Metabolism 81, 3424-3427.

Saad MJ, Araki E, Miralpeix M, Rothenberg PL, White MF \& Kahn CR (1992) Regulation of insulin receptor substrate-1 in liver and muscle of animal models of insulin resistance. Journal of Clinical Investigation 90, $1839-1849$.

Sakaue H, Hara K, Noguchi T, Matozaki T, Kotani K, Ogawa W, Yonezawa K, Waterfield MD \& Kasuga M (1995) Ras-independent and wortmannin-sensitive activation of glycogen synthase by insulin in Chinese hamster ovary cells. Journal of Biological Chemistry 270, 11304-11309.

Saladin R, De Vos P, Guerre-Millo M, Leturque A, Girard J, Staels B \& Auwerx J (1995) Transient increase in obese gene expression after food intake or insulin administration. Nature 377, 527-529.

Salomon F, Cuneo RC, Hesp R \& Sonksen PH (1989) The effects of treatment with recombinant human growth hormone on body composition and metabolism in adults with growth hormone deficiency. New England Journal of Medicine 321, 1797-1803.

Schwartz MW, Peskind E, Raskind M, Boyko EJ \& Porte D (1996) Cerebrospinal fluid leptin levels: relationship to plasma levels and to adiposity in humans. Nature Medicine 2, 589-593.

Shepherd PR, Nave BT \& Siddle K (1995) Insulin activates glycogen synthase by a novel PI 3-kinase/p70s6k dependent pathway in 3T3-L1 adipocytes. Biochemical Society Transactions 23, 202S.

Snyder DK, Clemmons DR \& Underwood LE (1988) Treatment of obese, diet-restricted subjects with growth hormone for 11 weeks: effects on anabolism, lipolysis, and body composition. Journal of Clinical Endocrinology and Metabolism 67, 54-61.

Sun XJ, Crimmins DL, Myers MG Jr, Miralpeix M \& White MF (1993) Pleiotropic insulin signals are engaged by multisite phosphorylation of IRS-1. Molecular and Cellular Biology 13, 7418-7428.

Sun XJ, Wang LM, Zhang Y, Yenush L, Myers MG Jr, Glasheen E, Lane WS, Pierce JH \& White MF (1995) Role of IRS-2 in insulin and cytokine signalling. Nature 377, 173-177.

Sutherland C, O`Brien RM \& Granner DK (1995) Phosphatidylinositol 3-kinase, but not p70/p85 ribosomal S6 protein kinase, is required for the regulation of phosphoenolpyruvate carboxykinase (PEPCK) gene expression by insulin. Dissociation of signaling pathways for insulin and phorbol ester regulation of PEPCK gene expression. Journal of Biological Chemistry 270, 15501-15506.

Takahashi J, Furuhata Y, Ikeda A, Takahashi M, Iwata H, Kazusaka A \& Fujita S (1999) Characterization of hepatic cytochrome $\mathrm{P} 450$ isozyme composition in the transgenic rat expressing low level human growth hormone. Xenobiotica 29, 1203-1212.

Tartaglia LA, Dembski M, Weng X, Deng N, Culpepper J, Devos R, Richards GJ, Campfield LA, Clark FT \& Deeds J (1995) Identification and expression cloning of a leptin receptor, OB-R. Cell 83, 1263-1271.

Thirone AC, Carvalho CR \& Saad MJ (1999) Growth hormone stimulates the tyrosine kinase activity of JAK2 and induces tyrosine phosphorylation of insulin receptor substrates and Shc in rat tissues. Endocrinology 140, 55-62.

Tojo H, Tanaka S, Matsuzawa A, Takahashi M \& Tachi C (1993) Production and characterization of transgenic mice expressing a hGH fusion gene driven by the promoter of mouse whey acidic protein (mWAP) putatively specific to mammary gland. Journal of Reproducion and Development 39, 145-155.

Trayhurn P, Hoggard N, Mercer JG \& Rayner DV (1999) Leptin: fundamental aspects. International Journal of Obesity and Related Metabolic Disorders 23, 22-28.

Turner ND, Knapp JR, Byers FM \& Kopchick JJ (1998) Expression of mutant bovine growth hormone genes in mice perturbs age-related nutrient utilization patterns. Journal of Nutrition 128, 520-524.

Veldhuis JD, Iranmanesh A, Ho KK, Waters MJ, Johnson ML \& Lizarralde G (1991) Dual defects in pulsatile growth hormone secretion and clearance subserve the hyposomatotropism of obesity in man. Journal of Clinical Endocrinology and Metabolism 72, 51-59.

Vigneri R, Pliam NB, Cohen DC, Pezzino V, Wong KY \& Goldfine ID (1978) In vivo regulation of cell surface and intracellular insulin binding sites by insulin. Journal of Biological Chemistry 253, 8192-8197. 
Virkamaki A, Ueki K \& Kahn CR (1999) Protein-protein interaction in insulin signaling and the molecular mechanisms of insulin resistance. Journal of Clinical Investigations 103, 931-943.

Wolfsdorf JI, Sadeghi-Nejad A \& Senior B (1983) Hypoketonemia and age-related fasting hypoglycemia in growth hormone deficiency. Metabolism: Clinical and Experimental 32, 457-462.

Wu-Peng XS, Chua SC Jr, Okada N, Liu SM, Nicolson M \& Leibel RL (1997) Phenotype of the obese Koletsky (f) rat due to Tyr793stop mutation in the extracellular domain of the leptin receptor (Lepr). Diabetes 46, 513-518.

Yamauchi T, Kaburagi Y, Ueki K, Tsuji Y, Stark GR, Kerr IM, Tsushima T, Akanuma Y, Komuro I, Tobe K, Yazaki Y \& Kadowaki T (1998) Growth hormone and prolactin stimulate tyrosine phosphorylation of insulin receptor substrate1, -2, and -3, their association with p85 phosphatidylinositol 3-kinase (PI3-kinase), and concomitantly PI3-kinase activation via JAK2 kinase. Journal of Biological Chemistry 273, 15719-15726.

Yip RG \& Goodman HM (1999) Growth hormone and dexamethasone stimulate lipolysis and activate adenylyl cyclase in rat adipocytes by selectively shifting $\mathrm{Gi}$ alpha2 to lower density membrane fractions. Endocrinology 140, 1219-1227.

Young RA (1976) Fat, energy, and mammalian survival. American Zoologist 16, 699-710.

Zhang Y, Proenca R, Maffei M, Barone M, Leopold L \& Friedman JM (1994) Positional cloning of the mouse obese gene and its human homologue. Nature 372, 425-432. 